\title{
Influence of surface and cloth characteristics on mechanical removal of meticillin-resistant Staphylococcus aureus (MRSA) attached to inanimate environmental surfaces in hospital and healthcare facilities
}

\author{
Mafu Akier Assanta ${ }^{1 *}$, Richard Massicotte ${ }^{2}$, Gilbert Pichette ${ }^{2}$, Sonia Lafleur ${ }^{1}$, \\ Marie-Josée Lemay ${ }^{1}$, Darakhshan Ahmad ${ }^{2}$
}

1. Food Research and Development Centre, Agriculture and Agri-Food Canada, St-Hyacinthe, QC, Canada

2. Laboratoire d'études sur le contrôle des infections nosocomiales (LECINO), Hôpital du Sacré-Cœur de Montréal, Montreal, QC, Canada

doi: 10.3396/IJIC.v9i3.021.13

\begin{abstract}
In health care facilities, the inanimate environmental surfaces can become contaminated with nosocomial pathogen agents. Cleaning and sanitization has already been accepted as an important and integral factor for controlling the transfer and spread of contaminants. With the advent of new cleaning utilities, there is a need to evaluate the benefits of adapting/ implementing new versus conventional utilities, both in terms of efficacy and cost. For instance, cotton and microfiber cleaning cloths (wipes/towelettes) may help in the removal of soils and attached bacterial cells. In this context, it is also important to know if the nature of the substratum surface can affect the cleaning output when we use both microfiber and cotton cloths. In this work, the role of physicochemical factors on bacterial adhesion to three inanimate/environmental surfaces, stainless steel, melamine and Formica laminate, was investigated by assessing the hydrophobicity by contact angle measurement method. In addition, the topography of the substratum surface and the attachment capability of meticillin-resistant Staphylococcus aureus (MRSA) to the surfaces were studied using scanning electron microscopy (SEM). The results obtained revealed that, with the exception of Formica laminate, MRSA cells could attach to stainless steel and melamine surfaces after short contact time of 24 hours. The outcome also indicated that in presence of soil/ organic matter, the microfiber cloths were only slightly more efficient for the removal of soil and attached microbial cells than the cotton cloths. However, for surfaces without soils, no significant difference was found when cotton cloths or microfiber cloths were used. It was also observed that regardless of the type of cloth material used or the presence of soil, the melamine surfaces were the most difficult ones to clean.
\end{abstract}

Keywords: Meticillin-Resistant Staphylococcus aureus; Textiles and Utilization; Healthcare facilities and Microbiology; Sanitation

\section{Corresponding Author}

Dr Mafu Akier Assanta, DVM, MSc, PhD, Postdoc

Food Research and Development Centre, Agriculture and Agri-Food Canada

3600 Casavant Boulevard West, St-Hyacinthe, QC, Canada J2S 8E3

Email: akierassanta.mafu@agr.gc.ca 


\section{Introduction}

In hospitals and healthcare facilities, environmental contamination makes an important contribution to nosocomial infections. Bacterial contamination and subsequent colonization of environmental surfaces has been demonstrated and reported frequently. For instance, meticillin-resistant Staphylococcus aureus (MRSA), a well-known human pathogen frequently found in a variety of environments, including the hospital environments. ${ }^{1-5}$ Across the world, despite of concrete efforts for the implementation of standard control practices in the healthcare systems, infections via meticillin-resistant Staphylococcus aureus (MRSA) have been widely reported with great concerns..$^{6-9}$ This strain has been identified as the cause of several nosocomial infections including tissue invasion, toxic shock syndrome (TSS), bacteraemia with a tendency to produce abscesses, invasiveness and thrombogenesis. ${ }^{6}$ Community acquired meticillinresistant Staphylococcus aureus (MRSA) is as well a growing concern. ${ }^{7}$ Under hospitals' favourable environmental conditions, deposition of the cells of this microorganism onto the environmental surfaces in health care facilities may result in proliferation and subsequent colonization of the surface, crosscontamination and outbreaks. In Canada, only in the province of Quebec, nosocomial infections represent an important cost for the health care system, for one MRSA infected patient, the expenses may reach up to $\$ 14000 .{ }^{4}$ For instance, between 2008 and 2009, 699 new persons infected by MRSA were reported in Quebec, costing approximately $\$ 9786000 .^{4}$

The common presence of this organism in the healthcare institutions strongly supports the notion that environmental contamination of inert materials may contribute to the transmission of this pathogen when patients come in contact with contaminated surfaces. Although bacterial adhesion to surfaces has been demonstrated in a wide variety of environments, ${ }^{11-14}$ the inert material surfaces continue to receive attention for the presence of attached contaminants. In a hospital, contaminated environmental surfaces can be a transmission vector in nosocomial infections. Bacterial adhesion to inert material surfaces is governed by physicochemical and electrostatic interactions between the surfaces of the cell wall and the substratum.
Generally, the bacterial attachment/adhesion is described as a two phase phenomenon. The first phase is nonspecific described by the DVLO theory (Derjarguin-Landau-Verwey-Overbook) includes the Van der Waals forces..$^{15-17}$ The second phase, called specific, comprises the molecular structures of microorganism and the charge of the supportive substratum surface ${ }^{15-17}$. The adhesion of bacteria on inert material is a function of different parameters that include physiochemical properties of the substratum surface and the characteristics of the bacterial cell wall. One of the most important properties of a surface is it's hydrophobicity/or hydrophilicity associated with the adhesion to inert surfaces. ${ }^{17-22}$ For this reason it is significantly important to, first, identify and understand the properties of the surface that can influence the cell attachment to that specified surface.

Stainless steel, melamine, and laminated Formica are three widely used structural/material components of the infrastructure and equipment in a hospital system. Melamine is used frequently in the construction of hospital furniture. All these three surfaces are considered hydrophobic, with contact angle value, a measure of the hydrophobicity evaluated with a drop of water, $>65^{\circ}$ (a value lower than $90^{\circ}$ is considered as hydrophilic and higher than $90^{\circ}$ as hydrophobic)..$^{23-24}$ Another important factor contributing to the bacterial adhesion is the roughness of the surface. ${ }^{18}$ The roughness of an inert surface can produce a microenvironment that is more favourable to the survival and propagation of specific pathogenic bacteria from both hospital and home environments. This characteristic could impose difficulty in appropriate cleaning and disinfection.

Mafu et al. showed that cells that are intimately associated with the inanimate material may be less susceptible to cleaning processes due to the protective boundary layer and the secretion of extracellular coatings. ${ }^{25-26}$ The ability of microorganisms to become more resistant to sanitizers and other antimicrobial agents once attached to the surfaces has been documented. ${ }^{27}$ For this reason it is necessary to use a good cleaning agent with a good cloth for a maximal elimination of bacterial population on the inert surfaces. 
Despite of the abundance of literature describing cleaning regimens, ${ }^{28-29}$ little is known about the adhesion of MRSA to the surfaces and decontamination efficiency of microfiber and cotton cloths for the surface-attached MRSA. Considering the widespread occurrence of MRSA in the hospital environment and its ability to survive on different types of environments, ${ }^{26}$ as well as its role as a nosocomial pathogen, we have initiated the present study to re-evaluate the efficacy of commonly used microfiber and cotton cleaning cloths for removal of the attached cells from three different surfaces types in the presence or absence of organic soil.

In Quebec healthcare system, microfiber cloths are frequently used to clean contaminant from melamine made furniture. This cloth has a better potential for elimination of contaminants from inert surfaces compared to cotton cloth due to the diameter and electrostatic properties of its fibers. However, since the cost of use of microfiber represents an important impact factor for the Quebec government economy; this independent study was conducted to compare the suitability of microfiber and cotton clothes in removal of the contaminants.

\section{Materials And Methods}

\section{Organism and culture condition}

Meticillin resistant Staphylococcus aureus (MRSA), a clinical strain, was obtained from the collection of Hôpital Sacré-Coeur (Montreal, Qc, Canada). Stock culture was stored at $-70^{\circ} \mathrm{C}$ in Trypticase soy broth (Difco Laboratories, Beckton Dickinson, MD, USA) supplemented with $20 \%(\mathrm{vol} / \mathrm{vol})$ sterile glycerol as cryoprotectant. Prior to each experiment, the suspension was subcultured ( $1 \% \mathrm{vol} / \mathrm{vol})$ in Trypticase soy broth (Difco Laboratories, Beckton Dickinson, MD, USA) and incubated at $37^{\circ} \mathrm{C}$ for 24 hours. Culture was pelleted at 3000g for 5 minutes (Eppendorf Centrifuge 5702r, Brinkmann, Ont, Canada) and resuspended in either bovine serum albumine $(5 \%)$ to simulate organic load or in saline water $(0.85 \%)$. Viable count was performed and the bacterial concentration was 5 x $10^{8} \mathrm{cfu} / \mathrm{ml}$.

\section{Test surfaces and soiling procedures}

Polished stainless steel (type 304, 2.0 mm thick; Acier inoxydable Syri, St-Félix de Valois, Qc, Canada), melamine (5.6 mm thick, \#992; Ébénisterie Prestige Inc., Joliette, Qc, Canada), and Formica laminate (\#51205289; Rona, St-Hyacinthe, Qc, Canada) were cut in $225 \mathrm{~cm}^{2}$ pieces. All materials were similar to those that are used in healthcare systems. The stainless steel was placed in sealing sterilization pouches (Chexall, Schuman Company, Propper manufacturing Co. Inc, NY, USA) and sterilized at $121^{\circ} \mathrm{C}$ for 30 minutes prior to each test. Melamine and laminate Formica were sterilized by irradiated by ionisation with cobalt 60 at a minimal dose of 15 KGy. Sterile surfaces were contaminated by spreading $500 \mathrm{ml}$ of bacterial culture and dried for 1 hour under laminar flow hood. In all cases, bacterial concentration before drying was $2 \mathrm{x}$ $10^{6} \mathrm{CFU} / \mathrm{cm}^{2}$.

\section{Surfaces cleaning}

Prior to cleaning, microfiber cloths (\#60M-F280B, Produits SANY Inc., Joliette, Qc, Canada) and cotton cloths (\#HW54579, Produits SANY Inc., Joliette, Qc Canada) were placed in sealing sterilization pouches (Crosstex international, NY, USA) and sterilized at $121^{\circ} \mathrm{C}$ for 30 minutes. Using sterile gloves, cloths were moistened by first soaking in sterile distilled water and then gently squeezing to remove excess water. Four back and forth moves, beginning on the upper left corner and ending on the lower left corner, were performed in order to clean the surface entirely with the moist cloth.

\section{Determination of surface population}

Sterile sponges (Speci-Sponge, B01245WA, Whirl-Pak, Fisher Scientific, Nepan, Canada) were moistened with $10 \mathrm{ml}$ peptone water $(0.1 \%)$ and three up and down moves were performed to swab the surface entirely. The sponge was transferred in a sterile stomacher bag containing $90 \mathrm{ml}$ of sterile peptone water. Homogenisation was performed at $230 \mathrm{rpm}$ for 30 seconds in a stomacher (Stomacher ${ }^{\circledR} 400$ Circulator, Seward, NY, USA). Enumeration was done by serial 10 -fold dilutions in $0.1 \%$ peptone water and plating each dilution into Trypricase soy agar (TSA, Difco Laboratories, Becton Dickinson, MD). The agar plates were incubated at $37^{\circ} \mathrm{C}$ for 24 hours before counting the colonies using colony counter 902A (Bantex, Taiwan). This technique is well recognized and used in food industry for evaluation of the presence and enumeration of bacteria recovered from a surface. ${ }^{30,31}$ 
The technique has been validated for the recovery of spores of Bacillus anthracis on a surface. ${ }^{32}$

\section{Scanning electron microscopy}

Sterile $1 \mathrm{~cm}^{2}$ surfaces of stainless steel, melamine and Formica laminate were immersed into a vial containing $10 \mathrm{ml}$ of $S$. aureus suspension at a concentration of $1 \mathrm{x}$ $10^{9} \mathrm{cfu} / \mathrm{ml}$ for a contact time of 24 hours at $37^{\circ} \mathrm{C}$. After the contamination period, the surfaces were aseptically removed from the broth suspension with forceps and drained by holding them vertically. They were manually rinsed three times for 1 minute each time in $0.1 \mathrm{M}$ sterile cacodylate (Marivac Ltd., Halifax, Canada) buffer ( $\mathrm{pH}$ 7.3) to remove unattached cells. Surfaces were fixed by immersion in glutaraldehyde $2.5 \%$ (vol/vol) (Ted Pella, Redding, CA, USA) in 0.1 $\mathrm{M}$ sterile cacodylate buffer, $\mathrm{pH} 7.3$, for 1.5 hours and washed four times in the buffer for 15 minutes before dehydration through a series of increasing ethanol concentrations $(30,50,70,80 \%$ and, finally three times with $100 \%$ ), performed for 15 minutes at each step. Specimens were mounted on stubs and covered with $9 \mathrm{~nm}$ of gold using a sputter coater (Cressing Tom 108, USA). A Hitachi S300N (Hitachi, Japan) scanning electron microscope operating at $5 \mathrm{kV}$ was used to observe the surfaces.

\section{Contact angle method for the measurement of surface hydrophobicity}

Surface hydrophobicity was evaluated through contact angle measurements cleaned stainless steel, melamine and laminate Formica surfaces used in the aforementioned part of the study. Contact angles were determined by the sessile drop technique using pure deionized water at room temperature. Measurements were performed automatically with the aid of an image analysis system installed in a goniometer (FTA 200, First Ten Angstroms, Portsmouth, VI, USA). Images were transmitted by a video camera (Prosilica, Allied Vision Technologies, Newburyport, MA, USA) to a computer for evaluation. At least 10 measurements were performed on each material.

\section{Statistical analysis}

Statistical analyses were performed with the SAS System for Windows (2008, SAS Institute Inc., Cary, NC, USA. Version 9.2). Analyses of variance were performed with the GLM procedure. Multiple comparisons of significant effects were performed with the Duncan test. Normality of the residues was tested with the Univariate procedure while the homogeneity of variances was tested with the Levene test of the HOV.

\section{Results}

Scanning electron microscopic (SEM) examinations of uncontaminated stainless steel, melamine, and Formica laminate surfaces are shown in Figure IA, IB, and 1C, respectively. To the naked eye, all surfaces appear to be very smooth; however, upon observation with SEM, all showed significantly different surface morphological characteristics. The stainless steel surface was distinctly marked by striated scratches and depressions (Fig. IA), whereas the melamine surface was smooth and marked distinctly by some particles and deposits (Fig. IB). The laminate Formica surface distinctly showed small holes that appear to be encrusted on the surface (Fig. IC).

Figure 2 shows electron micrographs of meticillinresistant $S$. aureus cells adhered/attached to stainless steel, melamine, and Formica laminate surfaces after 24 hours of exposure in the cell suspension at the ambient temperature. The stainless steel surface (Fig. 2A) and Formica laminate (Fig. 2C) were covered by fewer numbers of cells, in comparison to melamine that contained moderately higher number of attached cells (2B), despite the same length of exposure. In all cases, adherence and proliferation of $S$. aureus cells on the stainless steel and Formica laminate surfaces was difficult to assess accurately.

Data obtained from the contact angle measurement for the hydrophobicity of the three substratum surfaces is presented in Table I. It is interesting to note that in all three cases, the surface tension of two of the surfaces studied, Formica laminate and melamine, indicated their hydrophilic nature (the contact angle value being $<90^{\circ}$ ), the difference being relatively low $(76.1$ and $72.1^{\circ}$, respectively). The contact angle value for stainless steel surface was $92.2^{\circ}\left(>90^{\circ}\right)$, indicating its hydrophobic nature.

The results for the effects of microfiber and cotton fabrics on cleaning of MRSA cells, with or without organic soil matter, from stainless steel, melamine and Formica laminate surfaces are shown in Table II. In 

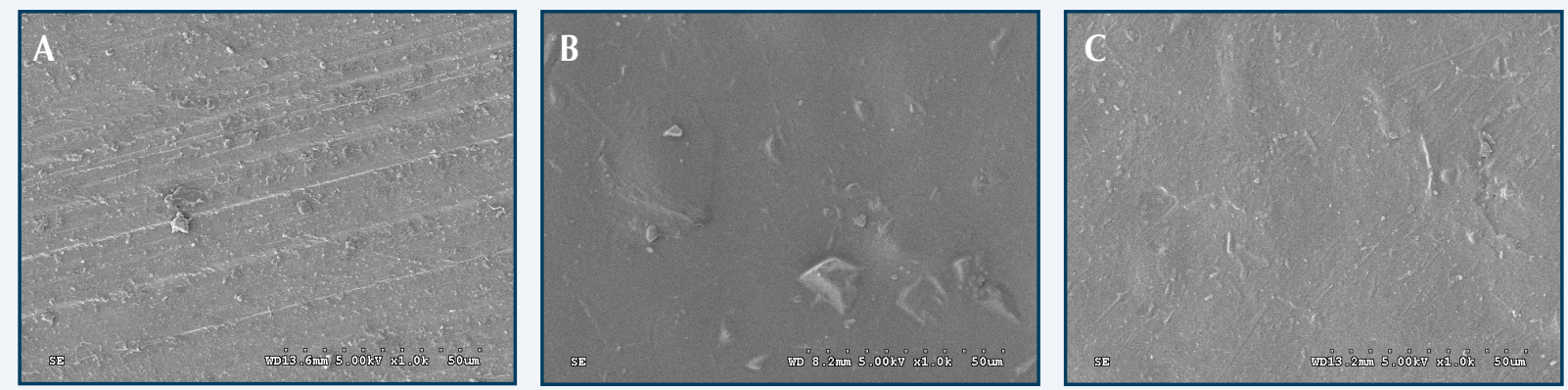

Figure 1. Overview of the structure of uncontaminated surfaces:

stainless steel (A), melamine (B), and Formica laminate (C)

Using scanning electron microscopy. Bar $=50 \mu \mathrm{m}$.
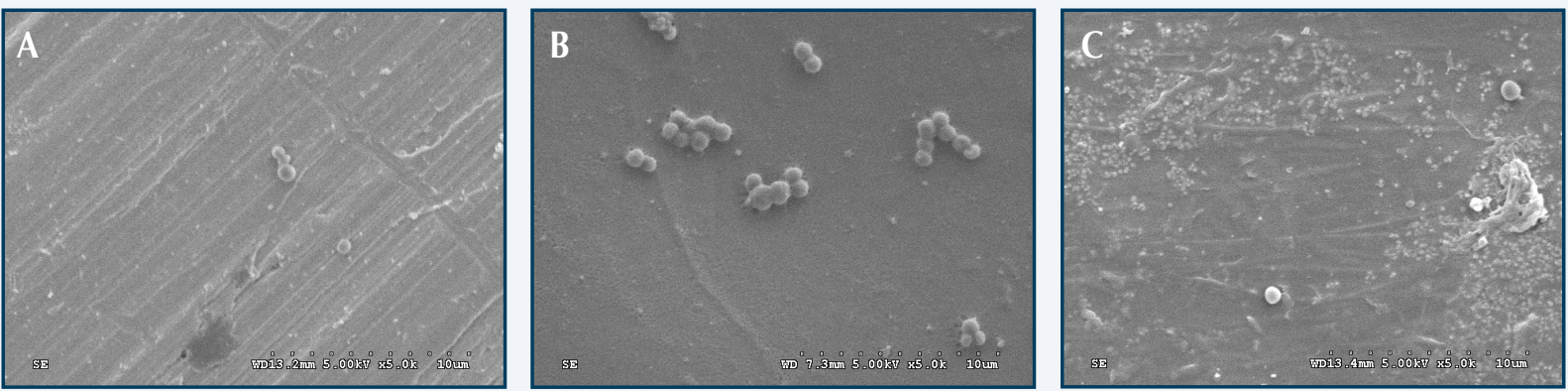

Figure 2. Scanning micrograph of MRSA cells attached to stainless steel (A), melamine (B), and Formica laminate $(C)$

After $24 \mathrm{~h}$ of contact. Bar $=50 \mu \mathrm{m}$.

comparison to the cotton cloths, the decrease/ removal of the bacterial population on all tested surfaces was more significant $(\mathrm{P}<0.05)$ with the microfiber cloths. However, the differences were not substantial $(0.24$ to $\left.0.75 \log \mathrm{cfu} / \mathrm{cm}^{2}\right)$. Furthermore, the differences between all tested surfaces taken together (Table IV) were not statistically significant. Nevertheless, a trend was identified $(p=0.057)$. The best bacterial loss (removal) was obtained with the microfiber cloth on the Formica surface in the absence of organic load (2.63 $\left.\log \mathrm{cfu} / \mathrm{cm}^{2}\right)$ and the most difficult surface to clean with the cotton cloth was melamine in presence of organic soil $\left(0.48 \log \mathrm{cfu} / \mathrm{cm}^{2}\right)$. Bacterial loss varied between 1.47 to $2.63 \log \mathrm{cfu} / \mathrm{cm}^{2}$ for surfaces without organic soil and dropped to 0.48 to $1.20 \mathrm{log} \mathrm{cfu} /$ $\mathrm{cm}^{2}$ in presence of organic matter (Table II). Thus, the presence of organic load, in all cases, had a significant effect $(p<0.05)$ on the cleaning efficiency, decreasing the cleanability of adhered cells.

The results of our study revealed that removal of MRSA cells from the three surfaces using moistened microfibre and cotton cloths, in presence or absence of organic matters (Table I), was the best while using microfiber cloth on the Formica surface (loss of 2.63 $\left.\log \mathrm{cfu} / \mathrm{cm}^{2}\right)$. In the presence of organic matter, the lowest bacterial loss/removal was associated with the melamine surface when using cotton cloth $(0.48$ $\log \mathrm{cfu} / \mathrm{cm}^{2}$ ). As shown in Table II, the statistical analysis of this study demonstrated that the cleaning efficiency was statistically $(p<0.0007)$ more effective when microfiber cloth was used as compared to the cotton cloth. Data presented in Table III shows that the bacterial average loss per $\mathrm{cm}^{2}$ of the treated surface is higher using microfiber cloth $\left(1.71 \mathrm{log} \mathrm{cfu} / \mathrm{cm}^{2}\right)$ than that of cotton cloth $\left(1.21 \log \mathrm{cfu} / \mathrm{cm}^{2}\right)$.

Interestingly, our results also indicated that, in the presence of organic matters, cleaning with water allows to obtain a bacterial loss varying from 0.48 to $1.20 \log \mathrm{cfu} / \mathrm{cm}^{2}$, whereas without organic matters, cleaning with water allows to obtain a bacterial loss of 1.47 to $2.63 \log \mathrm{cfu} / \mathrm{cm}^{2}$ (Table II). The average results, considering both, the substratum surfaces and 


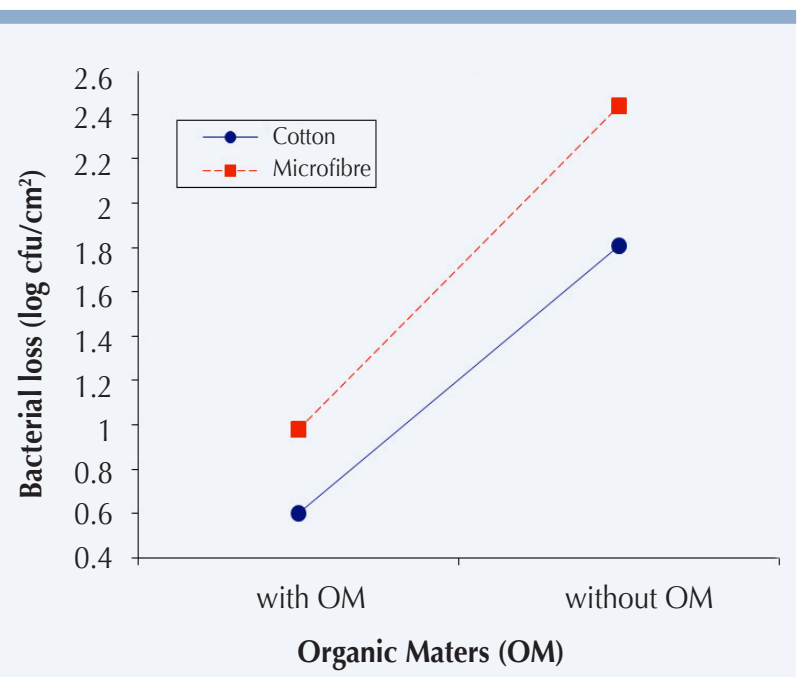

Figure 3. Cells removal average by cloth with and without organic maters

cleaning cloths merged together (Table III), indicates that in the absence of organic matter the loss per $\mathrm{cm}^{2}$ (2.12) is higher than the loss in the presence of organic matter (0.79). The presence of organic matters on the surfaces has a strong significant impact $(p<0.0001)$ on the efficacy of cleaning procedures. This effect, also demonstrated in Figure 1, clearly illustrates an absence of interaction and effect of the organic matter as well as the type of cloth on the surfaces.

With respect to melamine, it is worth mentioning that the minimum bacterial cell loss obtained for this surface means that it is the most difficult one to be cleaned, independent of the organic matters and type of cloth used. Although the statistical analysis did not show a significant difference (at $p=0.057$ ) between the surfaces, further experiments with more replicates are recommended to statistically clarify and validate this finding. A graphic representation of this tendency for the level of attachment of bacterial cells to different surface types is also observed in the Figure 2.

The slope of right segments is downward for melamine. Furthermore, in Table III, the average of the results by surface (cloth and organic matters taken together), gives bacterial loss values per $\mathrm{cm}^{2}$ of $1.59,1.56$ and $1.22\left(\mathrm{cfu} / \mathrm{cm}^{2}\right)$ respectively for the stainless steel, Formica and melamine.

\section{Discussion}

This study show the importance of the physicochemical characteristics of inanimate environmental surfaces

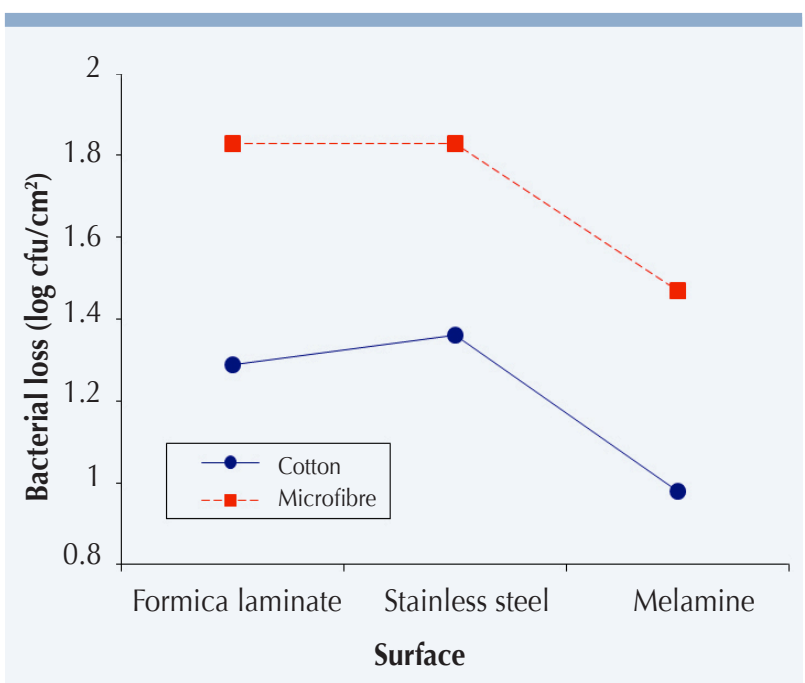

Figure 4. Cells removal average by cloth and surface

found in the hospital and healthcare facilities, influencing the output of cleaning, sanitation and infection control measures/protocols. The results obtained from the study can be largely understandable by the characteristics of surfaces because the latter play an important role on the bacterial adherence/

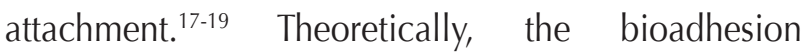
capacity of bacteria in general, as demonstrated with Staphyloccocus aureus in this study, is modulated by: a) the hydrophobic or hydrophilic nature of the substratum/support surface; b) the roughness of the surface of the substratum material, and c) the physicochemical characteristics of the bacteria cell wall. In fact, differences in the attachment ability of cells of $P$. aeruginosa and $S$. aureus have been shown to be due to the differences in their cell surface characteristics; adhesion of hydrophobic $P$. aeruginosa was more tenacious on contact lenses than hydrophilic S. aureus. ${ }^{33}$ In hospital environment, in general the nosocomial bacteria are associated principally with organic liquids (blood, faeces, urine, saliva etc.). In fact, our results show that MRSA strain do adheres to the surfaces in different ways depending upon the

\section{Table I. Contact angle measurements of different} surfaces tested using water

\begin{tabular}{lr} 
Surfaces & Contact angle (degree) \\
\hline Stainless steel & 92,0 \\
Melamine & 76,1 \\
Formica laminate & 72,1 \\
\hline
\end{tabular}


Table II. Water cleaning removal of MRSA bacterial cells attached to different surfaces using microfibre (M) and cotton $(C)$ cloths $\left(\log \mathrm{cfu} / \mathrm{cm}^{2} \pm\right.$ standard deviation).

\begin{tabular}{|c|c|c|c|c|c|c|}
\hline $\begin{array}{l}\text { Organic } \\
\text { load }\end{array}$ & $\begin{array}{l}\text { Stainless stee } \\
\text { Initial }^{1} \\
\text { population }\end{array}$ & Lost & $\begin{array}{l}\text { Melamine } \\
\text { Initial } \\
\text { population }\end{array}$ & Lost & $\begin{array}{l}\text { Formica lar } \\
\text { Initial } \\
\text { population }\end{array}$ & Lost \\
\hline With & $5.09 \pm 0.18$ & $\begin{array}{ll}\text { M } & 1.20 \pm 0.49 \\
\text { C } & 0.74 \pm 0.39\end{array}$ & $4.88 \pm 0.17$ & $\begin{array}{ll}\text { M } & 0.72 \pm 0.36 \\
\text { C } & 0.48 \pm 0.36\end{array}$ & $4.86 \pm 0.32$ & $\begin{array}{ll}\text { M } & 1.02 \pm 0.51 \\
\text { C } & 0.58 \pm 0.09\end{array}$ \\
\hline Without & $4.85 \pm 0.18$ & $\begin{array}{l}\text { M } 2.46 \pm 0.28 \\
\text { C } 1.97 \pm 0.11\end{array}$ & $5.32 \pm 0.11$ & $\begin{array}{l}\text { M } 2.22 \pm 0.31 \\
\text { C } 1.47 \pm 0.38\end{array}$ & $5.17 \pm 0.42$ & $\begin{array}{ll}\text { M } & 2.63 \pm 0.38 \\
\text { C } & 1.99 \pm 0.66\end{array}$ \\
\hline
\end{tabular}

${ }^{1}$ surface attached cell populations before cleaning

presence or absence of organic matter. The presence or the absence of organic matter influences the cleaning efficiency of both types of cleaning cloths (microfiber and cotton). The presence of the inorganic soil and dust can as well be another important factor that can modify the surface characteristics influencing the bioadhesion on the surface. These influencing factors are generally neglected or ignored. In this regard, additional data with inorganic soil or dust or particulates will be of great interest for understanding the surface interactions. The overall influence of organic and inorganic soil can modify the ionic strength/ charges on the surface and substratum hydrophobicity, and influencing adhesion that in turn can induce biofilm formation.
Scanning electron micrographic examination of treated surfaces confirmed that more cells remained attached to melamine surface (Fig. 2B) followed by stainless steel surface (Fig. 1A), and Formica surface (Fig. 2C) noting that debris was evident on the latest material. The attachment of $S$. aureus on stainless steel and melamine drew our attention because all three surfaces, similarly as Formica, are generally recognized to be of hydrophilic in nature. Thus, in theory, these should disfavour the bioadhesion. Generally, the majority of the microorganisms adhere to the surfaces of high hydrophobicity $\left(>90^{\circ}\right)$ and low surface energy (less than 30 dynes/cm2). ${ }^{34}$

Table III. Average lost of bacteria for different parameters.

Average $\left(\log \mathrm{cfu} / \mathrm{cm}^{2}\right)$

\begin{tabular}{ccc}
\hline $\begin{array}{c}\text { Surface } \\
\text { with organic loads, } \\
\text { all surfaces and cloths }\end{array}$ & $\begin{array}{c}\text { Cloths } \\
\text { without organic loads, } \\
\text { all surfaces and cloths }\end{array}$ & $\begin{array}{c}\text { Organic maters } \\
\text { with or without organic loads, } \\
\text { all surfaces and cloths }\end{array}$ \\
Stainless steel & Microfibre & with \\
1.59 & 1.71 & 0.79 \\
Melamine & & without \\
1.22 & Cotton & 2.12 \\
Formica laminate & 1.21 & \\
1.56 & & \\
\hline
\end{tabular}


It is interesting to note that melamine, according to our results, represents a surface where $S$. aureus adhered the most. Generally, a less significant number of bacteria become attached to hydrophilic substrata such as glass, mica, oxidized plastics that are charged negatively. ${ }^{34}$ Melamine surface, composed of materials similar to that of Formica, is also considered as being hydrophilic because of the low contact angle measured on this surface. Thus, additional factors may play important role in the attachment of $S$. aureus to this material. Hypothetically, these factors are the characteristics of the surface of the bacteria as well as a modification of the energy of the inert substratum surface because of its potential preliminary charge/ ionization during the contamination of the surface. ${ }^{34}$

In the case of the stainless steel, our results showed its hydrophobic nature with an angle of contact $>90^{\circ}$. Thus, it could have gone under a sudden modification of its basic characteristic, which is $80^{\circ}$ in presence of contamination according to the literature. ${ }^{36}$ According to Thongyai, ${ }^{29}$ surfaces with high surface energy charge (the hydrophilic in nature), are naturally less stable and on contamination have a tendency to react in a way to favour stability by decreasing the energy level. The reduction of surface energy can be the result of an oxidation, the presence of a protective cover, or simply the presence of contaminants such as residues of cleaning products and organic products. ${ }^{37-38}$ Thus, the use of organic soil matter in our works could have affected the microbial adhesion. ${ }^{37}$ It was also demonstrated that the presence of organic matter has an impact on the rate of bacterial population reduction depending upon the type of fabric material used (Fig. 3 ), being more difficult to clean in presence of soil for all three surfaces tested.

Microtopographs of the stainless steel surface (Figures 1 and 2) distinctly show the presence of streak all over its surface. The roughness of the surface is an important factor to consider in the bacterial attachment because it increases the available surface area for adhesion. ${ }^{18,38-39}$ In fact, a correlation between the surface available for attachment and cells attachment has been demonstrated. ${ }^{38-39}$ Thus, the hydrophobic characteristics of the used stainless steel could have been aggravated and enhanced by the roughness of the surface.
Table IV. The results of the analysis of variance

\begin{tabular}{lr} 
Source & p-value \\
\hline Surface & 0.0570 \\
\hline Organic maters (O.M) & $<0.0001$ \\
\hline Surface x O.M & 0.65 \\
\hline Cloth & 0.0007 \\
\hline Surface x cloth & 0.98 \\
\hline M.O. x cloths & 0.35 \\
\hline Surface x .O.M x cloths & 0.75 \\
\hline
\end{tabular}

Also, two additional factors may include the characteristics of exopolymeres produced by the bacterium and the hydrophobic or hydrophilic nature of the surface of the bacterium can contribute to explain the difference in adhesion of MRSA on the melamine and stainless steel. ${ }^{40-41}$ Each family of strains possesses its own physicochemical cell wall/surface properties, in space and time. In the case of $S$. aureus, Hogt et al. ${ }^{42}$ have suggested that the hydrophobicity of this microorganism is affected by the nature of extracellular proteins/ slime on its surface. However, it is of utmost importance to note that these characteristics are rather dynamic, not static, over time. They can change with the environment and the growth phase of bacteria, ${ }^{43-44-45}$ in space and time. Modifications of the energy characteristics of the surface of microorganisms can thus modulate the bacterial adhesion. ${ }^{46}$

The results obtained for the cleaning with both cloths (microfiber and cotton) seem to be a function of their interactions and capacity to break the physicochemical links between the inert substratum surfaces and the bacteria. The microfiber cloth consists of fibres of hydrophilic polyamide and hydrophobic polyester in a variety of concentrations controlled and specified by the manufacturer. The presence of these two types of fibres could, in theory, confer an advantage because this characteristic allows interaction, independent of the energy status on the surface of the inert support and the bacteria. The fineness/ sharpness of the strands of microfiber could also play an important role because this characteristic allows its passing through very small irregularities of surface in comparison to the cotton cloth. 
Researchers observed and reported a variation in the efficiency of removal of bacteria from a surface with microfiber cloths that are new and those that have gone through reprocessing, cycles of washing and drying. ${ }^{47-50}$ In our work, only new microfiber and cotton cloths were used. This could explain why our results indicate that microfiber cloth is slightly more effective in comparison to the cotton. Concerning the cleaning abilities of microfiber cloth, Smith et al. ${ }^{49}$ have reported that microfiber cloth, removed a little more organic matter as compared to cotton cloth while underlining that this cells removal was not significant. Similar results were obtained in the microbiological evaluation of microfiber and conventional cotton cloths for surface disinfection..$^{50-51}$ These observations corroborate with the results of this study since no significant differences were observed. This is even more evident when the cleaning of the surfaces was done in presence of organic matters. Thus, the routine use of microfiber cloth and its cleaning performance for hospitals' environmental surfaces remain controversial.

This finding corroborates with those reported by Moore and Griffith, ${ }^{50}$ which stated that there was no significant difference between the microfiber and conventional cotton in bacterial reduction/ removal. In their report on the efficacy of microfiber to decontaminate surfaces, they indicated that the cleaning ability of microfiber cloths was variable, and outlined that in most case, it was not significantly better than conventional cotton cloths.

Finally, the presence of organic matter seems to be one of the most significant factors influencing the efficacy of cleaning as because it can interfere with the efficacy of sanitization procedures in two major ways, by either inactivating the disinfectant or blocking it's surface contact. Generally, cleaning outputs are better on unsoiled surfaces than soiled ones, although the efficacy is reduced to a variable degree depending on multiple interacting factors, on the type of organic matter involved, type of substratum surfaces, cleaning product and cleaning techniques. ${ }^{51-54}$ Surface-attached bacteria also compromise the sanitation of inanimate surfaces due to the increased microbial resistance to disinfectants, and the subsequent colonization and biofilm formation and spreading of detached cells to other areas/ entities of hospital/ healthcare environment.

\section{Conclusions}

The findings on the attachment capabilities of MRSA observed in this study provide evidence that this, as well as other groups of nosocomial pathogens, that may contaminate the inert surfaces in health care facilities to a levels that may lead to the spread of the pathogen and, consequently, become a potential source of contamination of healthcare personnel, visitors, and others who come in contact with these surfaces. Stainless steel surfaces that are considered hydrophilic, thus better in disfavouring bacterial adhesion, may be subjected to change due to surface contamination but also by increasing the roughness over time. It also seems that the physicochemical characteristic of the melamine favours the attachment of hydrophobic cells of $S$. aureus on this surface, more so in presence of organic soil.

Results from this study, indicate that in presence of soil, in comparison to the cotton cloths, microfiber cloths seem to be slightly superior in removing microbial cells. In the absence of soil, no significant difference in cleaning output was found between the two cloths. Of three surfaces tested, melamine surface was found to be the most difficult to clean, regardless of the presence or absence of soil, or the type of cleaning cloth used.

Finally, since there is significant use of the melamine and the stainless steel in the constitution of furniture in the healthcare environment, more exhaustive studies to understand the dynamism of the physicochemical and bioenergetic interactions between the microbial cells and the "inanimate inert" environmental surfaces should be targeted. A better understanding of microbial adhesion vis a vis the inanimate surfaces in the hospital/ healthcare environment will not only lead to better infection control and cleaning strategies but in making informed decisions when building, renovating, furnishing, refurnishing and refurbishing the hospital and healthcare facilities. 


\section{Acknowledgements}

The authors would like to thank the Group of hygiene and healthiness at Sacré-Cœur Hospital, Montreal as well as the support services. We also express our thanks to the Ministry of Health and Social Services (Quebec) for their financial support, which made this project possible, and the Food Research and Development Centre, Agriculture and Agri-Food Canada at SteHyacinthe for the precious collaboration. Also, appreciations are addressed to Dr Ali Tahérian for his input.

\section{References}

1. Overesch G, Büttner S, Rossano A, Perreten V. The increase of methicillin-resistant Staphylococcus aureus (MRSA) and the presence of an unusual sequence type ST49 in slaughter pigs in Switzerland. BMC Veterinary Research 2011; 7: 30. http:// dx.doi.org/10.1186/1746-6148-7-30

2. Weese JS, Reid-Smith R, Rousseau J, Avery B. Methicillinresistant Staphylococcus aureus (MRSA) contamination of retail pork. Can Vet J 2010; 51(7): 749-752.

3. Nemati M, Hermans K, Lipinska U, et al. Antimicrobial resistance of old and recent Staphylococcus aureus isolates from poultry: first detection of livestock-associated MethicillinResistant Strain ST398. Antimicrob Agents Chemother 2008; 52(10): 3817-3819. http://dx.doi.org/10.1128/AAC.00613-08

4. Ministère de la Santé et des Services sociaux. La Direction de la protection de la santé publique rattachée à la Direction générale de la santé. Le Plan d'action sur la prévention et le contrôle des infections nosocomiales au Québec 2010-2015, 2011; ISBN : 978-2-550-61054-0, 90 p.

5. Dancer S. Importance of the environment in MeticillinResistant Staphylococcus aureus: the case for hospital cleaning. Lancet Infect Dis 2008; 8: 101-113. http://dx.doi. org/10.1016/S1473-3099(07)70241-4

6. Lowy F. Staphylococcus aureus Infections. N Engl J Med 1998; 339: 520-532. http://dx.doi.org/10.1056/ NEJM199808203390806

7. Zetola N, Francis JS, Nuermberger EL, Bishai WR. Communityacquired Meticillin-Resistant Staphylococcus aureus: an emerging threat. Lancet Infect Dis 2005; 5(5): 275-286. http:// dx.doi.org/10.1016/S1473-3099(05)70112-2

8. Boyce JM. Environmental contamination makes an important contribution to hospital infection. J Hosp Infect 2007; 65: 5054. http://dx.doi.org/10.1016/S0195-6701(07)60015-2

9. Boyce JM, Potter-Bynoe G, Chenevert C, King T. Environmental contamination due to methicillin-resistant Staphylococcus aureus: possible infection control implications. Infect Control Hosp Epidemiol 1997; 18: 622-627. http://dx.doi. org/10.1086/647686

10. Klevens RM, Morrison MA, Nadle J, et al. Invasive meticillinresistant Staphylococcus aureus infections in the United States. I Am Med Assoc 2007; 298: 1763-1771. http://dx.doi. org/10.1001/jama.298.15.1763

11. Doss RP, Potter SW, Soeldner AH, Christian JK, Fukunaga EL. Adhesion of germlings of Botrytis cinerea. Appl Environ Microbiol 1995; 61: 260-265.

12. Amaral MM, Coelho LR, Flores RP, et al. The predominant variant of the Brazilian epidemic clonal complex of methicillin-resistant Staphylococcus aureus has an enhanced ability to produce biofilm and to adhere to and invade airway epithelial cells. J Infect Dis 2005; 192: 801-810. http://dx.doi. org/10.1086/432515

13. Mafu, AA, Roy D, Montpetit D. Adhesion of Aeromonas hydrophila to water distribution systems pipes after different contact times. J Food Prot 1998; 61: 1321-1329.

14. Kalmokoff ML, Austin JW, Wan X-D, Sanders G, Banerjee $\mathrm{S}$, Farber JM. Adsorption, attachment and biofilm formation among isolates of Listeria monocytogenes using model conditions. J App/ Microbiol 2001; 91: 725-734. http://dx.doi. org/10.1046/j.1365-2672.2001.01419.x

15. Dellamonica P, L'adhérence bactérienne, CHU de Nice, 2012, Présentation au colloque sur les infections nosocomiales et orthopédie, Paris.

16. Hermansson M. The DLVO theory in microbial adhesion. Colloids and Surfaces B Biointerfaces 1999; 14: 105-119. http://dx.doi.org/10.1016/S0927-7765(99)00029-6

17. Boulané-Petermann L. Processes of bioadhesion on stainless steel surfaces and cleanability: a review with special reference to the food industry. Biofouling 1996; 10(4): 275-300. http:// dx.doi.org/10.1080/08927019609386287

18. Girard M, Attachement des Norovirus aux surfaces inertes et évaluation de leur sensibilité aux désinfectants domestiques. Mémoire présenté à la Faculté des études supérieures de I'Université Laval dans le cadre du programme de maîtrise en Sciences et technologie des aliments pour l'obtention du grade de Maître es Sciences (M. Sc.), Département des sciences des aliments et de nutrition, faculté des sciences de l'agriculture et de l'alimentation de l'université Laval de Québec 2009, 98 p.

19. Allion A, Environnement des bactéries et sensibilité aux biocides, Mise au point d'une technique rapide pour déterminer in situ l'efficacité bactéricide d'agents antimicrobiens, Thèse de doctorat, École nationale supérieure des industries agricoles et alimentaire 2004, France, 194 p.

20. Bellon-Fontaine M-N, Cerf O, Mécanismes d'adhésion des microorganismes aux surfaces: facteurs influant sur I'adhésion. Ind Alim Agro-Ind 1991; 108: 13-17.

21. Rosenberg M. Bacterial adherence to hydrocarbons: a useful technique for studying cell surface-hydrophobicity. FEMS Microbiol Letters 1984; 22: 289-294. http://dx.doi. org/10.1111/j.1574-6968.1984.tb00743.x

22. Smyth CJ, Jonsson P, Olsson E, et al. Differences in hydrophobic surface characteristics of porcine enteropathogenic Escherichia coli with or without K88 antigen as revealed by hydrophobic interaction chromatography. Infect Immun 1978; 22: 462-472.

23. Adamson W. Physical Chemistry of Surfaces, 5th edn. Wiley, New York, NY 1990.

24. Rios PF, Dodiuk H, Kenig S, McCarthy S, Dotan A. The effects of nanostructure and composition on the hydrophobic properties of solid surfaces. J Adhesion Sci Technol 2006; 20(6): 563587. http://dx.doi.org/10.1163/156856106777213302

25. Mafu AA, Plumety C, Deschênes L, Goulet J. Adhesion of pathogenic bacteria to food contact surfaces: Influence of $\mathrm{pH}$ of culture. Internat J Microbiol 2011; 2011: 1-10. http://dx.doi. org/10.1155/2011/972494

26. Mafu AA, Pitre M, Sirois S. Real-Time PCR as a tool for detection of pathogenic bacteria on contaminated food contact surfaces in a single enrichment medium. J Food Prot 2009; 72: 1310-1314.

27. Mafu AA, Roy D, Machika K. Efficacy of disinfecting agents to destroy Listeria monocytogenes, Yersinia enterocolitica and Staphylococcus aureus on a contaminated surface. I Dairy Food Environ Sanit 1996; 16: 426-430.

28. French GL, Otter JA, Shannon KP, Adams NMT, Watling D, Parks MJ. Tackling contamination of the hospital environment by methicillin-resistant Staphylococcus aureus (MRSA): a comparison between conventional terminal cleaning and 
hydrogen peroxide vapour decontamination. I Hosp Infect 2004; 57: 3137. http://dx.doi.org/10.1016/j.jhin.2004.03.006

29. Tongyai N. 'Study of stainless steel surface cleanability' Thesis submitted in partial fulfillment of the requirements for the degree of Master of Science, Department of industrial chemistry, King Mongkut's Intitute of Technology North Bankok, 2005, 75p.

30. Martínez B, Celda MF, Anastasio B, García I, López-Mendoza MC. Microbiological sampling of carcasses by excision or swabbing with three types of sponge or gauze. J of Food Prot 2010; 73(1): 81-87.

31. Gill CO, Badoni M. Effects of experience with swabbing procedures on the numbers of bacteria recovered from carcasses by swabbing with sponges. / Food Prot 2010; 73(4): 747-751.

32. Rose LR, Hodges L, O'Connell H, Noble-Wang J. National validation study of a cellulose sponge wipe-processing, method for use after sampling Bacillus anthracis spores from surfaces. Appl Environ Microbiol 2011; 77(23): 8355-8359. http://dx.doi.org/10.1128/AEM.05377-11

33. Bruinsma GM, van der Mei HC, Busscher HJ. Bacterial adhesion to surface hydrophilic and hydrophobic contact lenses. Biomaterials 2001; 22(24): 3217-3224. http://dx.doi. org/10.1016/S0142-9612(01)00159-4

34. Callow ME, Fletcher RL. The influence of low surface energy materials on bioadhesion - a review. Int Biodet Biodeg 1994; 34(3-4): 333-348. http://dx.doi.org/10.1016/09648305(94)90092-2

35. An YH, Friedman RJ. Concise review of mechanisms of bacterial adhesion to biomaterial surfaces. I Biomed Mat Res 1998; 43: 338-348. http://dx.doi.org/10.1002/(SICl)10974636(199823)43:3<338::AID-JBM16>3.0.CO;2-B

36. Salustiano VC, Andrade NJ, Ribeiro Junior Jl, et al. Controlling Bacillus cereus adherence to stainless steel with different cleaning and sanitizing procedures used in dairy plants. Arq Bras Med Vet Zootec 2010; 62(6): 1478-1483. http://dx.doi. org/10.1590/S0102-09352010000600026

37. Vanhaecke E, Remon JP, Moors M, Raes F, De Rudder D, Van Peteghem A. Kinetics of Pseudomonas aeruginosa adhesion to 304 and 316-L stainless steel: role of cell surface hydrophobicity. Appl Environ Microbiol 1990; 56: 788-795.

38. Allion A, Baron JP, Boulang-Petermann L. Impact of surface energy and roughness on cell distribution and viability Biofouling. J Bioad Biof Res 2006; 22(5): 269-278.

39. Rosenberg M. Bacterial adherence to hydrocarbons: a useful technique for studying cell surface-hydrophobicity. FEMS Microbiol Letters 1984; 22(3): 289-295. http://dx.doi. org/10.1111/j.1574-6968.1984.tb00743.x

40. Rosenberg M, Gutnick D, Rosenberg E. Adherence of bacteria to hydrocarbons: a simple method for measuring cell-surface hydrophobicity. FEMS Microbiol Letters 1980; 9: 29-33. http:// dx.doi.org/10.1111/j.1574-6968.1980.tb05599.x

41. Eginton PJ, Gibson H, Holah J, Handley PS, Gilbert P. Quantification of the ease of removal of bacteria from surfaces. J Microbiol 1995; 15: 305-310.

42. Hogt AH, Danker J, Feijen J. Encapsulation, slime production and surface hydrophobicity of coagulase-negative staphylococci. FEMS Microbiol Letters 1983; 18: 211-215. http://dx.doi.org/10.1111/j.1574-6968.1983.tb00480.x
43. Mamo W, Rozgonyi F, Brown A, Hjertén S, Wadström T. Cell surface hydrophobicity and charge of Staphylococcus aureus and coagulase-negative staphylococci from bovine mastitis. I App/ Bad 1987; 62: 241-249. http://dx.doi. org/10.1111/j.1365-2672.1987.tb02405.x

44. Wadström T, Hjertén S, Jonsson P, Tylewska S. Hydrophobic surface properties of Staphylococcus aureus, Staphylococcus saprophyticus and Streptococcus pyogenes. A comparative study. In Staphylococci and staphylococcal infections. J. Jeljaszewicz (ed.). Zbl. Bakt 1981, Suppl. 10. Gustav Fischer Verlag, Stuttgart, 441-447.

45. Reifsteck F, Wilkinson BJ. Hydrophobicity/hydrophilicity of staphylococci. Abstracts of the Annual Meeting of the American Society for Microbiology, 1984; K-19, 150.

46. Wood JM, The interaction of microorganisms with ion exchange resin. In Microbial adhesion to surfaces. Berkeley RCW, Lynch JM, Meiling J, Rutter P, Vincent B (eds.) 1980, Ellis Horwood, Chichester, UK, 163-165.

47. GrivetM, MorrierJJ, Benay G, BarsottiO. Effect of hydrophobicity on in vitro streptococcal adhesion to dental alloys. Journal of Materials Science: Materials in Medicine 2000; 11(10): 637642. http://dx.doi.org/10.1023/A:1008913915399

48. Diab-Elschahawi M, Assadian O, Blacky A, et al. Evaluation of the decontamination efficacy of new and reprocessed microfiber cleaning cloth compared with other commonly used cleaning cloths in the hospital. Am I Infect Control 2010; 38(4): 289-292. http://dx.doi.org/10.1016/j.ajic.2009.09.006

49. Smith DL, Gillanders S, Holah JT, Gush C. Assessing the efficacy of different microfibre cloths at removing surface micro-organisms associated with healthcare-associated infections. J Hosp Infect 2011; 78(3): 182-186. http://dx.doi. org/10.1016/j.jhin.2011.02.015

50. Rutala WA, Gergen MF, Weber DJ. Microbiologic evaluation of microfiber mops for surface disinfection. Am / Infect Control 2007; 35: 569-573. http://dx.doi.org/10.1016/j. ajic.2007.02.009

51. Moore G, Griffith C. A laboratory evaluation of the decontamination properties of microfibre cloths. I Hosp Infect 2006; 64: 379-385. http://dx.doi.org/10.1016/j. jhin.2006.08.006

52. Wren MWD, Rollins MSM, Jeanes A, Coën PG, Gant VA. Removing bacteria from hospital surfaces: a laboratory comparison of ultramicrofibre and standard cloths. I Hosp Infect 2008; 70(3): 7. http://dx.doi.org/10.1016/j. jhin.2008.07.017

53. Gonzalez-Fandos E, Sanz J, Garcia-Fernandez MC, GarciaArias MT. Effectiveness of disinfectants used in the food industry on microorganisms of sanitary interest. Acta Alimentaria 2005; 34: 253-258. http://dx.doi.org/10.1556/AAlim.34.2005.3.7

54. Kawamura-Sato K, Wachino J, Kondo T, Ito H, Arakawa Y. Reduction of bactericidal activities in clinically isolated Acinetobacter species in the presence of organic materials. J Antimicrob Chemother 2008; 61: 568-576. http://dx.doi. org/10.1093/jac/dkm498 